\title{
African American Men and Intimate Partner Violence
}

\author{
Earl Smith
}

Published online: 27 February 2008

(C) Springer Science + Business Media, LLC 2008

\begin{abstract}
Drawing on interviews with African American males in violent intimate relationships, this paper focuses on individual causes (exposure to violence), cultural causes (constructions of masculinity) and structural causes (unemployment and incarceration) of intimate partner violence (IPV) among African American men. IPV is "triggered" by two threats to masculinity, though I focus exclusively on the first trigger (breadwinning). The analyses are framed by Merton's strain theory (1968) and his theory of unintended consequences (1976). I argue that at least for African American men, this framework when added to feminist theory and masculinity theory extends our understanding of battering, from the perspective of the batterer, beyond what other models have been able to accomplish. In short, from the point of view of many batterers, battering provides an accessible mechanism for African American men - who live in a social world plagued by a system of racial dominationto reassert their masculinity and thus maintain their male privilege and dominance in their heterosexual relationships. Yet battering has the unanticipated consequence of alienating them further from these same intimate partners, thus perpetuating the cycle of violence.
\end{abstract}

Keywords African American men · Intimate partner violence · Incarceration ·

Battering

Have you ever hit a black woman? I wish I had a nickel for every bitch whose ass I've put my foot in! I'd be so rich right now that you lames would have to put in your requests six months in advance just to get in to see me, let alone sit down at the same table with me!...Black women take kindness for weakness. Leave them the least little opening and they will put you on the cross. I hate a

\footnotetext{
E. Smith $(\square)$

Wake Forest University, Box 7549 Reynolda Station, Winston-Salem, NC 27109 USA

e-mail: smithea@wfu.edu

를 Springer
} 
black bitch. You can't trust them...You may not believe this but when I off a nigger bitch I concentrate real hard.

-Eldridge Cleaver, Soul on Ice

(Cleaver 1968 p. 68)

Currently, one of the most pressing issues for contemporary Black sexual politics concerns violence against Black women at the hands of Black men.

-Patricia Hill Collins, Black Sexual Politics: African Americans, Gender, and the New Racism. (Collins 2004 p. 225)

I never heard my friends say they wanted to be like their fathers when they grew up....A two parent home is no better off than a single parent one if the father is fucked up in the head and beaten down. There's nothing more dangerous and destructive in a household than a frustrated, oppressed black man.

-McCall, Makes Me Wanna Holla (1994 p. 83)

"I am proud of you for not crying."

- Rapper R. Kelly to his son Robert, Jr.

album liner notes, DOUBLE UP

\section{Introduction}

The tragedy for African American families and the African American community is that for centuries the family provided the social support and protection from the racism African Americans experienced routinely in the outside world (Allen et al. 2002). What intimate partner violence-IPV - accomplishes is the alienation of African American men from the very people who are standing there supporting them, protecting them from all kinds of racist acts ranging from job discrimination to police brutality: their female partners (Collins 2004; Hill 2005; Potter 2004).

The tragic irony in IPV is that the very racism that African American men rely on their female partners to buffer is also the source of the antagonisms that lead to so much of the abuse they perpetrate against these same female partners. ${ }^{1}$ Thus IPV not only rips apart the African American family but it leaves African American men (and women) more vulnerable to the racism perpetrated against them from the outside. This is what it means to argue that race shapes IPV. As I show in this paper, race shapes not only the acts of violence themselves but also the outcomes of the violence on individuals, families, and communities.

This paper focuses on the justifications African American men give for engaging in violence against their intimate partners. This topic is compelling because as many African American feminists argue, the greatest threat to the physical safety of

\footnotetext{
${ }^{1}$ In interview after interview these men shared with me the most intimate details of what they perceived to be unfair racial injustices perpetuated against them most often in their quest to find work.
} 
African American women is not "the white man," but the African American men with whom they choose to partner (Collins 2004; Hooks 2004; Potter 2004).

This paper is not an indictment of African American men and violence. Though I focus on African American men who perpetrate severe violence against their female partners, it is important to note at the outset that in their intimate relationships African American men are no more likely to be violent than their White counterparts (Hattery 2008). Yet, when African American men do engage in intimate partner violence (IPV) the violence they perpetrate is more severe than that employed by their White counterparts. $^{2}$ In this paper I explore the ways that race shapes experiences with IPV by examining IPV through the lenses of African American men who perpetrate it. After analyzing the data presented in this paper I conclude that all men in US culture are susceptible to engaging in battering as a response to threats and challenges to their masculine identities - specifically the failures they experience in breadwinning — but that the types of violence that African American men perpetrate are more severe because of the increased exposure they have to structural and institutional inequality that adds to the weight they unload on their female partners. Given that, my proposals for solutions are primarily focused on reducing IPV by reducing the types of structural inequalities that make it more difficult for African American men to deal with conflict in their relationships in less violent ways.

Finally, I note that this paper is not a comparison of White men's IPV experiences and the IPV experiences reported to me by African American men.

\section{Intimate Partner Violence}

In order to understand the power of the stories of the men that are told in this paper, we must first have a context for these experiences. Statistics on IPV provide an appropriate context that allows us to better interpret these experiences.

Many women in the USA experience violence within their own homes, exacting upon them severe physical, emotional, and economic costs (Browne 1989; Koss et al. 1994). The Center for Disease Control (CDC 2006) estimates that women are nine times more likely to be injured in their homes than in the streets; domestic violence accounts for more injuries to women than car accidents, muggings, and rapes combined. In 2006 women reported 4.8 million acts of violence (CDC 2006).

Domestic violence can also be lethal; in 20041544 women were murdered by their intimate or ex-intimate partners (CDC 2006). Domestic violence homicide accounts for $33 \%$ of all female homicides each year (USA Today 2003; http://www. ojp.usdoj.gov/bjs/homicide/gender.htm); with beatings being the most common method of murder (Browne 1989; Rennison 2003).

Large scale surveys (Tjaden and Thoennes 2000) reveal that approximately one in four men $(25 \%)$ indicate that they engaged in an act of violence against their intimate partner during the previous year. The most common types of violence include slapping, pulling hair, throwing things at their partner, and "beating her up" (Tjaden and Thoennes 2000).

\footnotetext{
${ }^{2}$ Data not shown. Requests for a detailed table comparing rates of IPV by race of the offender and race of the victim should be made directly to the author.

Springer
} 
Given these statistics it is not surprising that the research on men who batter is focused primarily in two areas: differentiating men who batter from the rest of the male population (Hanson et al. 1997; Holtzworth-Munroe and Stuart 1994) — what makes batterers different from "regular" men- and evaluating the efficacy of interventions with men who batter (Hirschel et al. 1992; Pate and Hamilton 1992; Sherman et al. 1992).

One of the shortcomings of the existing research on men who batter is that very little has focused on batterer's perceptions of the violence in which they are engaging (Goodrum et al. 2001). Rather, what we know about the dynamics of battering in couples is limited almost exclusively to data provided in the accounts of the female victims (Browne 1989; Goodrum et al. 2001).

In that context, the limited research that includes the voices of batterers comes almost exclusively from the evaluation literature of intervention programs. A variety of programs have been implemented but with only limited success in treating battering primarily because, according to Adams (1988), they seldom incorporate the victim's perspective into treatment. Rather, Adams suggests that many interventions attribute the battering to external forces, such as alcoholism or depression. By designing treatment protocols around these "social problems", which are clearly linked to battering (Hanson et al. 1997), instead of the core issue, which Adams' defines as the batterer's need to retain and enforce power over his partner, many interventions are only moderately effective (Adams 1988; Hattery et al. 2005). Finally, there is scant literature on non-white men who batter, specifically African American men. This paper is designed to address the void.

Finally, when IPV is a Black on Black occurrence the matter is ignored almost entirely, ${ }^{3}$ unless there is a death that is particularly gruesome, as was a case in April 2007. Timothy Shepherd, a young, African America male, was jealous of his exgirlfriend Tynesha Stewart's new boyfriend and after her murder, in a bizarre attempt to dispose of her body he burned her body to a crisp on a BBQ grill (CNN 2007). This obliviousness to Black on Black crime, which is further exacerbated when the violence is "domestic" and the victim is a Black woman (Hamberger et al. 2007), is in striking contrast to the over-attention paid to African American men as violentwhich is further exacerbated when the victims are White women; indeed the most common images of African American men are as perpetrators in actual crimes, thugs in films and music videos (Glassner 2000; Katz 2006), and "out of control" athletes (Smith 2007). ${ }^{4}$

The tough guy - or what Jackson Katz calls "tough guise"-in or out of athletics is a creation of the socialization process for African American males. Here we find the strong messages that to make it in this world you must be tough and uncompromising.

\footnotetext{
${ }^{3}$ In some of the early research on "Black on Black" crime there was hardly any mention of men beating their women. The almost exclusive concern was male on male violence. See, especially Poussaint 1972. Why blacks kill blacks. New York: Emerson Hall. STOP.

${ }^{4}$ In the athletic realm, when I think of the masculinity problematic I have to focus on the African American athlete, collegiate and professional (e.g., Taylor Bradford, Jean Taylor, Patrick Dennehy and others) who have their promising lives cut short by the very young African American males who mock them at the same time they love and adore them. These events present themselves as very unclear idiomatic puzzles in need of disentanglement.
} 


\section{Causes of Intimate Partner Violence}

Since most IPV (85\%) is male against female (Hattery and Smith 2007; Katz 2006; Tjaden and Thoennes 2000), it is time that we start paying attention to how men see their situations in these matters. Missing in the IPV research are studies of men who batter, especially research conducted in non-treatment settings (Gondolf 2008). Their perspectives will give us a more powerful portrait of this serious social problem and a perspective that is necessary in our attempts to solve this social problem and reduce IPV (Gondolf 2007). The existing literature on IPV identifies three "causes" for male violence: individual, cultural, and structural. I review these findings here.

\section{Individual Causes}

In terms of individual "causes", I follow the leads given in the work of Hattery (2008). I argue that men don't just batter because they can (Browne 1989; Hattery 2008; Straus and Gelles 1995) but they batter because they have seen battering in their childhood and adapted it as a strategy to control their intimate partners. Ehrensaft and Cohen (2003) report that experiencing child abuse doubles one's risk for beating one's intimate partner. But witnessing violence in childhood triples one's risk for growing up to become a batterer. Few researchers dispute the fact that child abuse and/or growing up witnessing intimate partner parental violence is detrimental to the healthy development of children. Yet, discussions of the intergenerational transmission of violence theory are wrought with controversy. Critics of the intergenerational transmission of violence theory point to the fact that the majority of boys who grow up in violent homes do not grow up to abuse either their children or their female partners (Dunlap et al. 2002). This is an important critique. And, others are critical of the term because it implies a genetic transmission. Yet, the point of the matter seems to be more that the important process in intergenerational transmission is not genetics but socialization. Boys who grow up in violent homes, particularly in homes where their father (or father figure) beats their mother, learn potent lessons about IPV that they carry with them into their adult relationships (Bogat et al. 2002).

\section{Cultural Factors}

From an early age, most children raised in the US will ascribe qualities such as strength, power, height, and money to boys and men (Connell and Messerschmdt 2005; Connell 1998, 1995). Kimmel (1993, 2005a, b) traces the origins of the fusion of these masculine traits with being male. The sheer correlation between these qualities and being a man in this country illustrates the path through which masculinity has come to be exclusively associated with being male. Men are "essentialized" by the traits, such as physical strength, that are associated with masculinity. Despite differences by race, ethnicity, sexual orientation, social class, and a variety of other factors which suggest there are really several "masculinities" (Connell 1998, 1995; Kimmel 2005a, b), the image by which most men judge themselves and are judged by others can be boiled down to a few qualities or 
statuses - including athlete, successful professional, and proficient with cars and fishing reels - as suggested by scholars of masculinity.

For a host of scholars, this narrow construction of hegemonic masculinity defines two basic roles for men: breadwinner and sexual conquistador (Anderson and Umberson 2001; Connell and Messerschmdt 2005; Howson 2006; Mullaney 2007). ${ }^{5}$

In using the concept of hegemonic masculinity I am not engaging in the rancorous debate around the concept itself (Connell and Messerschmdt 2005; Howson 2006) that many other scholars have devoted their careers to. For me, simply put, the concept of hegemonic masculinity provides a framework for describing and analyzing what I observed in the men I interviewed, specifically the way they accepted their patriarchal privileges with impunity and played out their "male roles" with their female partners. In sum, they were overbearing, stubborn, sexist, and most importantly for this paper, violent. This last point is very important in that in the initial development of the concept, hegemonic masculinity did not require violence as an essential element, though as Connell and Messerschmdt note, violence can be an outgrowth of the privileges and benefits associated with hegemonic masculinity (2005 p. 832)

Men who received the benefits of patriarchy without enacting a strong version of masculine dominance could be regarded as showing a complicit masculinity. It was in relation to this group, and to compliance among heterosexual women, that the concept of hegemony was most powerful. Hegemony did not mean violence, although it could be supported by force.

My primary concern with masculinity theory as it is developed by Connell and others has been the relative ignoring of race/ethnicity and social class differences. That said, Connell and Messerschmdt's focus on the role that structural factors play in the construction of masculinity renders their work useful in examining masculinity among African American men. It is also important to acknowledge the contribution of Therborn (1980) and others (Mills 1992; Shelton and Wilson 2006) who argue that though marginalized groups often develop alternative ideologies that are more in-line with their lived realities, despite the development of alternative ideologies, most members of any society are most heavily influenced by the ideologies that dominate their social world (Marx and Engels 1998).

\section{Structural Factors}

Based on the focus of Kimmel and others (Hattery 2008) on the importance of the breadwinner role in the construction of masculine identity, two structural factors are considered that severely impeded African American men's ability to successfully meet their proscribed masculine role and carry-out the breadwinner role: systematic discrimination in the labor market and disproportionate experiences with incarceration. Both were identified in previous work (Hattery and Smith 2007) as significant "triggers" to African American male battering (Sokoloff and Dupont 2005; West 2004).

\footnotetext{
${ }^{5}$ This paper is focused on the struggles African American men have with breadwinning and IPV. For a discussion of the role that sexual conquest plays in African American male IPV, see Hattery and Smith 2007.
} 
Labor Market African American men have faced historic discrimination in the labor market in terms of both hiring and wages (Padavic and Reskin 2002; Pager 2007). As a result, African American men face significantly higher rates of unemployment (often twice the rate of White men). Furthermore, African American men earn substantially less, only $62 \%$ of their White counterparts, and they are significantly more likely to be living in poverty (Heflin and Pattillo 2006). As a result, African American men find it significantly more difficult to meet the breadwinner requirement essentialized by hegemonic masculinity (Anderson 2008).

Incarceration More than one million African American men are incarcerated in American jails and prisons and over the lifecourse $25 \%$ to $33 \%$ of all African American men will be incarcerated (Hattery and Smith 2008). In 2005 nearly as many African American men were incarcerated as the entire world-wide work force employed by McDonalds (Pager 2007, p. 28). Incarceration not only removes men from the labor market during the period of their incarceration, but a jail or prison record, particularly if it is a felony, substantially restricts their post-incarceration employment opportunities (Mauer and Chesney-Lind 2002; Pager 2007; Smith and Hattery 2007; Western 2006).

No reasonable scholar would argue that unemployment and/or incarceration in and of themselves are pathways to battering. However, when unemployment, underemployment, and/or incarceration restricts a man's ability to meet the breadwinner role, this threat to a man's sense of his own masculinity may be a "trigger" for engaging in IPV. Nor is this paper an attempt to justify African American male battering as excused by Black men's position in society and in their fractured relationship with the police, criminal justice system and/or labor market (Pettit and Western 2004; Wacquant 2001). In fact too much attention is mis-placed on seeing the prison as simply a warehouse instead, as Wacquant (2001) advises that we begin to analyze the relationship between the African American community and the prison as an extra-phenological function of the criminal justice system and, hence, as an instrument of control of the dispossessed African American male. It is important to remember that it is inside walls that violence is, if not learned, honed.

Finally, the excuse that African American females should be quiet about the violence in their intimate relationships is just that, an excuse (Collins 2004; Hooks 2004). What this paper is designed to accomplish is a more comprehensive understanding of the reasons African American male batterers give for their own violence so that we can better prevent IPV before it happens and interrupt it when it does occur.

\section{Methods}

The Sample

This paper is based on an ethnographic study of nearly 100 men and women living with intimate partner violence (Richards and Morse 2007). Specifically this paper, which is based on the larger study, is limited to in-depth, face-to-face interviews with 
25 African American men who batter. ${ }^{6}$ These interviews were conducted in the spring, summer and fall of 2004. Interview subjects were identified by community partners employed in agencies that intervene in domestic violence disputes. Specifically, half of the men interviewed were involved in a court-ordered batterer intervention program and the other half were clients of the county child protective services (CPS) unit as a direct result of the police being called to their homes during a battering episode in which their children were present.

In terms of social class, the 25 African American men I interviewed ranged across the social class spectrum with the exception that no men in the sample could be described as "upper class." Several were unemployed and living in poverty, but the majority were employed in occupations ranging from small business owners to painters to security guards to managers in the fast food industry. I estimated social class by using data on wages - by state - provided by Bureau of Labor Statistics website (http://www.bls.gov/bls/blswage.htm).

\section{Unemployed}

Working Poor - those earning less than the median household income

Their educational attainment was similarly varied; with the normative outcome being a high school diploma or GED.

\begin{tabular}{ll}
\hline No high school diploma or GED & $8(32 \%)$ \\
High school diploma or GED & $14(56 \%)$ \\
Education beyond high school & $3(12 \%)$ \\
\hline
\end{tabular}

With regards to incarceration, ninety percent had been incarcerated, two at the time of the interview.

Interviews were conducted in two parts of the country: North Carolina (the South) and Minnesota (the Midwest). For several reasons-including the southern subculture of violence theory - as well as significant regional differences in racial composition, political ideology, and laws regarding intimate partner violence-it was important to collect data in two distinct regions of the USA. Despite these regional variations, there were in fact no differences in the types or lethality of the violence reported across regions.

The Interview

Interviews were designed to follow a semi-structured set of questions. The men were asked to begin by talking about the families in which they grew up, what the relationships were like between their parents, among their siblings, with grandparents and so on. The men were then asked to talk about their own experiences with dating and marriage or cohabitation. The focus was on both their "healthy" or violence-free relationships as well as the relationships that involved IPV. Thus the

\footnotetext{
${ }^{6}$ Fifteen white men who batter, 20 White women and 35 African American women who have been battered were also interviewed. Details on these additional interviews can be obtained from the author.
} 
interviews were essentially mini life-histories, each lasting between an hour and a half and two hours.

\section{Coding and Analysis}

I began with an interest in experiences with violence and the triggers to intimate partner violence that the men themselves identified. Because my sample is limited to men who have battered, I am unable to predict which men will batter and which will not. These data, however, were ideal for examining the experiences of a group of men who batter and illuminating the mechanisms by which men came to batter women they claimed to love. Specifically, my analysis allowed me to identify three "causes"individual, cultural, and structural—and two key "triggers"7 — "breadwinning" and "the bedroom"- to battering that were consistently present in the stories from these men. These "triggers" are interpreted through the lens provided by fusing Kimmel's (2005a) perspective on masculinity with Merton's (1968) notion of alienation.

\section{The Stories}

So when men talk about their violence they are continuing being men and doing masculinities as well as giving specific accounts of those violences. The doing of men's talk is just one more aspect of the social construction of men and masculinities. It is not a separate activity that needs to be read off and interpreted from prior social constructions of the way men have been "brought up" or the way masculinities have been "formed." Men's talk about violence is not an effect of the past, it is men doing masculinities themselves in the present (Hearn 1998 p. 213).

The "triggers" that African American male batterers identify need to be contextualized as having roots in the three factors identified above: individual cause, cultural causes, and structural causes. I begin with a discussion of individual factors.

\section{Individual Factors: The Intergenerational Transmission of Violence}

Many scholars argue that the most important way to understand the movement of violence across time is to differentiate between (a) individual behavior and (b) structural constraints. Professor Henry Louis Gates articulates clearly the tension between individual level choices and structural choices and puts it this way (Gates 2004):

It's important to talk about life chances - about the constricted set of opportunities that poverty brings. But to treat black people as if they're helpless rag dolls swept

\footnotetext{
${ }^{7}$ In this paper I deal only with the breadwinner "trigger." To read about the bedroom "trigger" see Hattery and Smith 2007. 
up and buffeted by vast social trends - as if they had no say in the shaping of their lives - is a supreme act of condescension. Only 50 percent of all black children graduate from high school; an estimated 64 percent of black teenage girls will become pregnant. (Black children raised by female "householders" are five times as likely to live in poverty as those raised by married couples.) Are white racists forcing black teenagers to drop out of school or to have babies?

When examining the lives of men who grow up to batter we must acknowledge that they make many bad choices; first and foremost they make the choice to hit, kick, punch, or beat up their female partners, women they claim to love. I won't defend these men's choices to batter their partners. But, in order to further our understanding of battering so that we might better prevent it from happening in the first place we need to understand something about the context in which many of these bad choices are rooted: growing up in violent homes.

Though, as I noted above, discussions of intergenerational transmission of violence are fraught with controversy, to ignore the fact that boys who grow up experiencing violence and/or witnessing it often grow into men who perpetrate it would be to ignore one of the processes by which IPV becomes part of intimate relationships. Indeed it would also be dismissive to ignore the powerful impact of childhood violence on the men I interviewed. Eddie grew up in a very violent household.

She would go downtown and take out warrants out on him and restraining orders and he'll go back and one night she took and killed him, you know they got into a fight, and one night she took and got it, they got into a fight, and she grabbed a pistol and shot him in the head, and he got killed the day before I had to go to court and go to training school, and uh, I went to training school at the age of 14 years old. I didn't know where my mother was at, she was going with guys that would sell her drugs, you know, she was doping you know. (Eddie, forty-something African American man, North Carolina).

Most boys who grow up in violent homes do not grow up to become abusive themselves. But, the impact of the abuse they witness or experience is severe nonetheless. And, for so many of the men I interviewed the homes they grew up in were extremely violent. In some cases they experienced violence themselves, but far more commonly they watched their fathers (or step-fathers) beat their mothers. Two men I interviewed, Manny in North Carolina and Will in Minnesota spoke to the issue of witnessing violence in their homes while growing up:

Yeah, yeah, but I don't want him [my son], you know what I mean, to grow up and go through what we been through, you know what I'm sayin', I believe in discipline, I give out spankin's, but I just don't want him to go through what me, my brother, and my sister went through with this dude [his step-father], you know what I'm sayin', cause I still got scars from when he beat us. He beat me with an extension cord, hit me in the face, yeah, he left a scar down my face, you what I'm sayin', so I had to stay out of school for a while on that, you know. He used to taunt my brother all the time. You're a punk, you're a pussy, you're a pussy, you know what I'm sayin', you ain't never gonna be nothing, you're stupid, dumb (Manny, thirty-something African American man, North Carolina). 
Will articulates the relationship between the abuse he suffered growing up and his use of violence as a father:

So you know, with my boys now, all the anger and stuff that I done been through, you know, anger management class, I see it coming out in my boys. One of them....and now he, he a little wiry guy and wants to play football. He's rough. He had the nerves the other day, he said, dad, I know what I want to do. I said, what? He said, I want to box. First thing that came to my mind was, oh no. It's because my dad used to get into it, used to always fight with my mother. He says [about his brother] I'm going to knock him out. They go in, the other morning, brushing their teeth, he turn around, keep messing with me, he keep messing with me. So, I just turned around and boom, popped him in the stomach [his son talking]. (Will, fifty-something African American man, Minnesota).

This confirms the finding that Straus and Gelles (1995) and others have reported that boys who grow up watching their fathers (or step-fathers) beat their mothers are at the greatest risk for growing up to beat their own female partners (Ehrensaft and Cohen 2003). I turn now to a discussion of cultural factors.

\section{Cultural Factors}

The majority of the men I interviewed identified insecurities about their ability to earn a living as a major cause to their violent behavior. Masculinity scholars (Kimmel 2005 b) provide a theoretical framework for understanding not only the cause - the inability to earn a wage - but also the "triggers;" specifically that when men feel their masculinity is threatened this serves as a "trigger" to their violent outbursts.

\section{Threats to the Breadwinner Role}

Practically speaking this "threat" means that men acknowledged battering when they felt nagged about not earning enough money or when they experienced feelings of low self-esteem as a result of their chronic unemployment and underemployment.

Eddie - who is also quoted above - owns a small painting company and he is a professional boxer. He has been involved in several violent relationships with exgirlfriends as well as with his wife. When I asked Eddie to talk about conflict in his marriage he indicated that they frequently argued about money.

Small stuff, you know. She's always complaining about that I don't treat her like a wife, because I don't buy her what she wants, things like I can't afford, she always throw up in my face like what her friend's husband, what kind of car he bought her and what kind of gifts he bought her. Of course he can buy her a brand new car when he, the assistant chief executive at Wachovia. And uh, she a RN, got a master's degree at Wake Forest, you know, and she complain about, oh and he just bought this 160 thousand house and you know you married me and you supposed to do this for me and my children, well what you, what you gonna do for yourself, and she always just nick nagging at me. (Eddie, thirtysomething African American man, North Carolina) 
From Eddie's perspective not only is this nagging unwarranted, he sees himself as a good provider who is doing the best he can, ${ }^{8}$ but his wife is not contributing financially to the household. "My wife hasn't worked, man, right now she don't even work. She, we don't get no kind of assistance, we don't get no kind of assistance, I make the money. She just get a little small child support check from their father, that's it?"

Eddie and his wife have had numerous arguments about her spending habits, the fact that she doesn't work, and her perception that he is not an adequate provider. These arguments often involve yelling and sometimes physical violence that is not limited to pushing and shoving.

Its important to note here that just a week or so before the time of my interview, Eddie had killed his opponent in the boxing ring and he appeared as a guest on the ESPN program "cold pizza" and in his interview detailed the experience from the boxing ring. Thus, even violence Eddie identified using "mild" terms could be lethal to his victim. Next, I examine the structural factors that contribute to IPV.

Structural Factors: The Labor Market and Incarceration

\section{The Labor Market}

African American men face a unique set of challenges and barriers with regards to employment. Nearly three centuries of slavery followed by a century of Jim Crow segregation have had long-lasting effects on African American men. It is often difficult to identify root causes of social problems (Brush 2006), as many of the issues that face African American men have multiple causes and multiple effects, but especially with regards to IPV, one of the critical issues is the persistent limited access that African American men have to the opportunity structure. African American men face both overt and covert racism and discrimination with regards to education, political power, job opportunities, leadership in all fields, and economic self-sufficiency. When the unemployment rate runs at $4 \%$ or $5 \%$ for the US population at large, it is often three to four times higher (15-20\%) for African American men. In fact, African American men face a far more dire day-to-day situation in terms of employment than is indicated by official statistics (Eckholm 2006; Mincy 2006). And, the inability to earn a living wage has direct implications for IPV, specifically as a "trigger": "failure as provider" which I detailed above.

\section{Incarceration}

The effects of incarceration are devastating to the African American community (Patterson 1999, 2007). My interviews with African American men (and women) living with intimate partner violence allowed me to identify a strong and important relationship between incarceration and battering. All but two of the African American batterers I interviewed had been to jail or prison and these periods of

\footnotetext{
${ }^{8}$ Not only does Eddie own his own company, but he has accomplished this without a high school diploma and with a criminal record.
} 
incarceration as well as the difficulties a felony creates for sustainable employment upon release contributed significantly to the violence in these families.

One of the most serious consequences of incarceration for ex-convicts is getting sustainable employment that provides a living wage. I note here the work of sociologist Pager (2007) who found that African American men with a felony record were "called back" for job interviews less than 5\% of the time (Pager 2007, p. 70); in contrast White males with a felony were three times more likely to be called back (17\%). Thus, the impact of incarceration and re-entry on individual African American men, their families and the African American community is both complex and devastating.

During the course of their 5 year relationship, Chris has repeatedly been incarcerated. He is unemployable because of his felony record and his stints in jail and prison. Wanda's accusation that Chris is a failure as a provider is interpreted by Chris as a threat to his masculinity - a "trigger." In an attempt to reassert his masculinity the argument escalates and often becomes physical.

This nigga got the biggest knife it is in the house laying on the counter. So I looked at him, so I eased right? I eased back to the back door and I seen him walk toward the front door. I comes up in the house and I grabbed the knife. And I take the knife and I puts it behind my back in my panties right here, like this right, put my t-shirt over it. I say, do it make any sense for you to act like a fool like you do? Calling that lady house, acting a fool. I said, Chris, it don't make no sense. I said, you know what you need to do? You need to get your shit, get together and get your shit out of here. I said, cause you got exactly two hours. If your shit ain't gone, you ain't got a place to go, far as I'm concerned, its garbage. I'm not putting up with your shit no more. I'm just through. 'oh, you just talking that shit, goddamn, cause you been over there drinking all night with Angela. She fooling your head full of bullshit.' I said, no, you got my head full of bullshit. I said, I'm tired now. So, but no, he ain't listen. 'You is my wife til death til we die.' So now that's when you start. That don't mean til death do you die like we done took no marriage vows. Til death do you die-either you're going to be woman or one of us going to be dead. You see what I'm saying. That's how I interpret it. Okay, so now wait a minute. So then, should I kill this motherfucker? (Wanda, forty-something African American woman, Minnesota).

This imbalance of economic power provides for Chris a key justification for beating his intimate partner. He recognized Wanda's economic power as a threat to his masculinity, his sense of himself as a man. In short, Chris beat Wanda and threatened her with the knife when he felt his masculine identity, specifically his economic power in the household, was threatened.

Additionally, what is absent in the literature on incarceration, although it is so very important to understanding IPV, is a discussion of jealously and infidelity. Many, if not all, the men I interviewed who were incarcerated and most of the women I interviewed whose partners were incarcerated reported infidelity. One man I interviewed, Hank said that he had women on the side while his partner was incarcerated and that this was not "cheating" because she knew about it. This interpretation was repeated over and over.

Chris, who was very jealous of men hanging around his girlfriend Wanda, noted that while he was in jail there was nothing he could do about it and he was not Springer 
worried, as long as she didn't fall in love with anyone else. In fact, he reinforced this point by stating: "I sleep through the night here, [in jail] I don't have any worries." Despite Chris' lackadaisical attitude, jealousy is the number one "trigger" to IPV (Browne 1989; Hattery 2008) and despite what Chris told me this was clearly an issue in Chris and Wanda's relationship.

During his periods of incarceration, Wanda makes friends with other men who continue to call her and come by after Chris is released back into the "free world." On a typical evening or weekend when Chris is "out", other men call and drop by "their" house to see Wanda. This is a major trigger for Chris. He is jealous. When he tries to physically assert what he sees as "his right to his woman", Wanda "reminds" Chris that he is not the breadwinner in the household and therefore has no claim to enforce the "rules."

My house. I'm paying all the bills. I'm talking about rent, gas, light, phone, cable, everything. Everything. Everything. I even buy his deodorant, okay? So who are you? 'I don't want nobody around my woman.' All this and that, this and that. 'What you want with my woman? Don't be calling my house!' But this is his house he say. I'm like, I said, 'mother fucker, this ain't your damn house. This is my mother-fucking house! You can get the fuck out!' So now I'm mad. Now I'm like get the hell out (Wanda, forty-something African American woman, Minnesota).

As these stories point out, incarceration is a conduit for IPV. Not simply because men who are in prison are socialized toward violence, but also because as Wright (1997) points out, prisons are a structure that cordons off African American men, in particular, from the labor market thus seriously impacting their ability to achieve masculine status by acting as breadwinners. And, as noted, prisons serve to cordon off African American men from their families and communities which further increase the likelihood that they will engage in IPV when they return home.

\section{Synthesizing Theory}

I use the stories (data) provided by the African American male batterers I interviewed to propose a "synthesis" approach to understanding IPV, at least from the perspective of the African American male batterer. Specifically, though I have most often relied on feminist theory and the race, class and gender paradigm to explain the social phenomenon that I study, in this paper I argue that feminist perspectives on IPV would be improved, at least in reference to discussions of African American men who batter, by borrowing a concept from the structural functionalists; specifically I suggest that Merton's work on alienation and deviance can help to unlock further the reasons why African American men (and maybe all men) beat up the women they claim to love.

Theoretically speaking, I am not adopting Structural-Functionalism (S/F) as a theoretical tool to understand IPV, a phenomenon that I consider to be "gendered." Furthermore, I am well aware, and it is perfectly understandable, that feminist scholars have mostly discarded S/F because it is "conservative" on gender issues. 
For example, Parsons and Bales (1955) argued that women were better suited to housework than to labor market work because they are genetically pre-disposed to childrearing. However, I argue that a feminist understanding of IPV and specifically of the reasons for male battering would be enhanced by borrowing the concept of alienation from Merton (1968). This important contribution from Merton, considered from a feminist perspective, will go a long way in advancing our understanding of and ability to explain the African American male batterer.

Merton's concepts of alienation and unanticipated consequences (1976) are both part of his larger theory of deviance known as strain theory. Essentially Merton argued that when alienation is experienced (strain) a social actor will seek a behavioral response designed to minimize his or her feelings of alienation. Each of the three "causes" of battering that I outlined above-individual, cultural, and structural - can all be interpreted as different forms of "strain," each of which calls for a behavioral response designed to reduce the strain.

This is similar to Kimmel (2005b) when he argues that one outcome of the contemporary political, economic, and social climate replete with declining real wages for men and soaring unemployment (as high as 50\% for African American men in places like New York City) is the difficulty men, and African American men in particular, face in establishing a masculine identity predicated on success - or the lack thereof - in the labor market. Gainful employment as a marker of masculinity is, in the current climate, tenuous at best, and leaves these men feeling threatened by the possibility that they are not masculine enough. "At the grandest social level and the most intimate realms of personal life, for individuals and institutions, American men have been haunted by fears that they are not powerful, strong, rich, or successful enough" (Kimmel 2005b, p. 8). In response to this failure at breadwinningand ultimately at establishing a masculine identity_Kimmel argues: “...American men try to control themselves; they project their fears on to others; and when feeling too pressured, they attempt to escape" (2005b, p. 9). And, one thing batterers have found they can control — through intimidation and violence-is their female partners (Hattery 2008).

And, while I argue that "borrowing" the concept of alienation-and unintended consequences - form Merton helps explain why African American men behave violently towards their intimate partners, I also understand the major shortcoming of the structural functionalist perspective, namely that structural functionalists assume a level playing field and they refuse to acknowledge inequality regimes (Acker 2006) that produce structured power and privilege that accrue to those in dominant (majority) positions. Specifically the work of Kimmel (2005a) and Hattery (2008), both of whom employ feminist theory in their work, underscores that a perspective that pays attention to the unequal and institutionalized distribution of power and privilege is necessary in explaining $W H Y$ men are violent towards their intimate partners to begin with. Namely, that society is organized by a gender inequality regime (Acker 2006; Epstein 2007) that imbues men with a sense of entitlement toward and ownership of their female partners (Lichtenstein 2005). I note here that the men I interviewed felt (and acted on these feelings) a specific entitlement to use violence against their women.

One way to expand our understanding of IPV is to understand battering as a mechanism that men-like those I interviewed-resort to as their first response to 
this state of alienation or anomie. ${ }^{9}$ And, while these may be individual perceptions and choices, they are, in fact, also consequences of structural factors and the dislocation from society.

\section{Alienation/Anomie}

I argue that the framework provided by Merton's strain theory is useful in understanding "triggers" to IPV as they are experienced and interpreted by African American men who batter. Working from this model, I argue that battering can be understood as a behavioral reaction to a state of anomie or normlessness. ${ }^{10}$ The "causes" of battering that are identified above - individual, cultural, and structuralcan all be understood as forms of strain. Whether it is the strain of being unemployed, the strain of incarceration, the strain of developing a masculine identity in a society dominated by white supremacy, or the strain of growing up in household terrorized by IPV, men who experience strain, especially that which represents a threat to their masculinity, may engage in violence against their female partners as a behavioral response designed to alleviate the strain. Yet, as I will discuss below, not only is this behavioral response problematic in and of itself, it may have the unanticipated consequence of further alienating the batterer from his intimate partner.

Let me note: I am not arguing here that African American men who are unemployed or who have been incarcerated or who witnessed IPV in their families of orientation are destined to become batterers. What I am arguing is that institutionalized racial inequalities - in the labor market, in incarceration, in foster care- leave African American men alienated from social institutions, and among other things, less able to meet the obligations of breadwinner in their families. Furthermore, incarceration separates men from their families which can lead to jealousy which is a primary "trigger" for battering as identified by other feminist scholars (Browne 1989; Hattery 2008). In fact the separation created by incarceration is yet another form of severe alienation. Thus, incorporating the concept developed by Durkheim and Merton is useful (Durkheim and Simpson 1979).

\section{Unanticipated Consequences}

Another aspect of IPV that would benefit from co-opting the concept of alienation from Merton (1976) is the "honeymoon" period that is a well-document phase of the cycle of IPV (Walker 1984). Feminist scholars have been adept at describing the honeymoon phase and analyzing its power in convincing victims of IPV to stay with their abusive partners. But, what has received little attention from scholars and what

\footnotetext{
${ }^{9}$ I would suggest that the men I interviewed are similar in many ways to other men who batter. What differentiates these men is their race. Because African American men face higher rates of discrimination in the labor force (Pager 2007. Marked: Race, crime, and finding work in an era of mass incarceration. Chicago, IL: University of Chicago Press.), higher rates of incarceration (2004. "Criminal Offenders Statistics." Bureau of Justice Statistics, Washington, DC) and are more likely to have witnessed violence as kids, the "triggers" I discuss herein are particularly more potent in their relationships with women.

${ }^{10}$ In looking for clearer and better ways to define anomie, I ran across the medical term dysphoria which is interesting in that it is defined as a state of feeling unwell or unhappy. In thinking about anomie I would add that the men I interviewed were also very unhappy in their intimate relationships.
} 
feminists have been relatively unsuccessful in explaining, are the underlying roots of the honeymoon phase from the perspective of the batterers themselves.

Feminists argue that IPV is a result of the gendered power relations that derive directly from patriarchy. Men hit because they can (for reasons of empowerment, gendered power etc.), and because it is effective in getting women's attention and sometimes in changing their behavior. But, stopping the analysis at this point assumes that men are necessarily satisfied with all of the outcomes of the battering episode. Based on the accounts of 25 African American men who have battered, most of whom have engaged in what I consider to be severe violence (beating their partners beyond recognition, threatening them with guns, and threatening to burn the house down), I argue that stopping the discussion at the point of noting that men can hit and that is it effective misses the "unanticipated consequences" of this violence. Specifically battering alienates these men from their intimate partners.

Applying the notion of alienation to the honeymoon phase I argue that this phase is best understood as a reaction to the alienation - an unanticipated consequenceproduced by the battering episode. This phase is employed by the batterer not out of empathy for his female partner, the victim of his violence, but rather in an attempt to re-establish the intimacy that his violent outburst destroyed. Once the intimacy is reestablished with his partner, the batterer once again experiences alienation with the world outside his relationship - alienation from the labor market, alienation from access to the American Dream, etc.- the "causes" identified above. And feeling his masculinity threatened-which may be "triggered," according to him-by the nagging of his intimate partner, he responds to this alienation by engaging in another episode of violence against his intimate partner and the cycle continues.

Many of the men I interviewed began the interview with the following: "I never intended to hit or hurt her." Furthermore, many men made it clear that not only did they not intend to hurt their intimate partners when they battered them, they never intended to grow up to be the type of man who batterers a woman he loves.

But I still look at it like this. I think as far, you know, young men we come up and we gonna see our mothers and our fathers together, you know we come up and we that get that thing going on, you know, like my moms was married to my real dad I did see him slam her head on the car, I was in the car, I did see that one, so you know, I think I think these young men when we see that when we children and as we grow up we like I'd never do that when I get married. I get married I never do that, I ain't gonna say this I ain't gonna do that to my wife, but when we grow up you know what I'm sayin', not knowin', you know what I'm sayin', in our mind, that's what we really been taught to do, that how we been taught to deal with things, you know, moms say something she smack in the mouth or somethin' like that, that kind a stick with guys you know, well guys say I ain't gonna do this, I ain't gonna do that, but when they get in the situation that do exactly that, you know (Manny, twenty-something African American man, North Carolina)

Part of the cycle of IPV is the unanticipated consequence of alienation that the batterer experiences in his relationship with his intimate partner. Analyzing the behavior of batterers from the perspective of alienation underscores the work of scholars whose research has demonstrated that batterers use denial to protect their self-concepts, often failing to acknowledge the inappropriate nature of their actions; 
batterers have very little understanding of the violence from the perspective of their wives or partners (Goodrum et al. 2001). Indeed they have a limited ability to take the role of the other in the context of this power relationship (Goodrum et al. 2001).

Wells is an African American man I interviewed in North Carolina. He was charged with assault and child endangerment for holding his wife and daughter hostage at gun point. The trigger for the event, according to Will, was finding out that his teenage daughter was sexually active. At the time of the interview his wife was living in the battered women's shelter and his daughter had moved in with her boyfriend. Despite the fact that there is a restraining order that prevents Wells from coming in physical contact with his wife, he fully expects them to reconcile. Note in his comments that he talks only about what she does for him.

But I enjoy life with my wife. I always tell her that if she go before I go that I wouldn't have anybody else. Not that marriage has been bad but I've been with her so long now I'm set in my ways and there ain't nobody else gonna respect me the way she respect me and what I mean by respect is that ain't nobody gonna do for me like she has done you know (Wells, fifty-something African American man, North Carolina).

In other words, batterers tend to see the action only through their own eyes and this inability to empathize with the victim leaves them surprised when she pulls away from them after a battering episode - the unanticipated consequence. This alienation from their intimate partner triggers another behavioral reaction to the strain: the honeymoon phase. During this phase the batterer attempts to seek intimacy with his intimate partner by showering her with gifts or being attentive and affectionate. As feminists explaining the honeymoon phase have noted (Browne 1989), this strategy is often effective. However, after re-establishing intimacy with his partner, the batterer once again focuses on his alienation from the social world, which frequently triggers another episode of IPV and the cycle of violence continues.

In short, a single act of violence that can make a man feel less alienated from his masculine role will likely lead to severe alienation from the one person who loves him: his intimate partner. Thus, I suggest that for many batterers the honeymoon phase may in fact be a sincere attempt to reduce the alienation from his intimate partner that his own act of violence created. This is a somewhat more nuanced argument than others have previously made (Franklin 1984), and which is based on my interviews with batterers who described how it felt to batter. Most found battering was an effective tool for changing the behavior of their wives and girlfriends, but they also noted that it was not particularly useful for establishing a healthy relationship.

As I have noted throughout this paper, one of the critical questions plaguing scholars of race, family, and IPV in particular is the racial variation in experiences with IPV. As noted, national level data reveal that race does not shape one's probability for engaging in IPV, but it does shape the types and lethalness of the violence that is perpetrated. This paper has focused on analyzing African American men's own explanations for their violent behavior. My analysis demonstrates that though the "causes" and the "triggers" for violence may not vary across race, ${ }^{11}$ the

${ }^{11}$ The White men I interviewed reported exactly the same "triggers"- - threats to one's masculine identity as "breadwinner" and in the "bedroom." 
structural inequalities that African American men face-specifically discrimination in the labor market and incarceration-lead to higher levels of alienation, stronger threats to one's masculine identity, and consequently the utilization of more severe violence to alleviate the high levels of strain. In addition, African American men are disproportionately likely to have experienced violence in the families in which they grew up. This exposure to violence puts them at increased risk for battering in adulthood. Merton's framework provides an unique and useful way of thinking about the racial variation evident in the statistics on IPV.

The Gun and Triggers: Why Batterers Batter and Explaining Racial Variation

One way of thinking about risks for or "causes of" perpetrating IPV (unemployment, incarceration, exposure to violence in childhood, alcohol and drug abuse, age, number of children, social class) as opposed to "triggers" for IPV (failures at breadwinning) is to use the analogy of a gun. The risks for or "causes" of IPV are like bullets that get loaded into the chamber of a gun. The "triggers" are the incidents (like being nagged by one's partner, jealousy) that men say lead to them erupting violently-like pulling the trigger on the gun. The "triggers" that African American men in this study report do not differ from the "triggers" that White men report in other research studies (Hattery 2008). Furthermore, these "triggers" are consistent with the threats to masculinity identified by Kimmel (2005a), Messner (2007) and others. How then is the greater use of force by African American men compared to their White counterparts - a fact that is well-documented by national level surveys of IPV - explained (Tjaden and Thoennes 2000). The argument being made here is that the primary way in which race shapes $I P V$ is by shaping the way in which the chamber of the gun is loaded.

African American men face many barriers to living successful lives (Anderson 2008; Mincy 2006). These include a substantially higher risk for incarceration, a significantly higher rate of unemployment, a significantly higher rate of underemployment and severe wage discrimination. If one imagines each of these experiencesincarceration, bouts of unemployment, earning sub-standard wages, etc. - as bullets that are loaded in the chamber of the gun, then we can see that for many African American men, the "guns" they hold are loaded with more deadly or lethal bullets than those held by their White counterparts. Thus, when African American men "pull the trigger" they erupt into more severe violence than their White counterparts. This "allegory" reveals the distinct way in which race shapes the expression of IPV, not the probability of engaging in IPV.

\section{Conclusion}

Well I'd rather my man would hit me

than for him to just up and quit me,

Ain't nobody's business if I do.

I swear I won't call no coppa,

型 Springer 
If I'm beat up by my Poppa

Ain't nobody's business if I do.

-Billie Holiday, 1930s

Using Brush's (2003) account of how the state promotes the dominance of men and the disadvantage of women, I conclude this paper by noting that until IPV is defined not only as a "women's problem" (Katz 2006) but also as a major public health problem and as a problem men need to address (Hattery 2008) there is little hope of reducing the epidemic of IPV. Unless we frame it this way, then we as a society will not act on the promise to protect women from all forms of IPV. Simply saying that we should send men to prison for beating their women just does not work. Why? As the scholar Hearn (1998, p. 79) notes "it is very unusual for men to receive a custodial sentence for violence to women."

And, it is worth stating again that the African American community needs to address the issue of the battering of African American women at the hands of African American men. ${ }^{12}$ Why? The feminist scholar Collins (2004, pp. 225-226) put it this way:

Currently, one of the most pressing issues for contemporary Black sexual politics concerns violence against black women at the hands of Black men.... Much of this violence occurs within the context of Black heterosexual love relationships, Black family life, and within African American social institutions. Such violence takes many forms, including verbally berating Black women, hitting them, ridiculing their appearance, grabbing their body parts, pressuring them to have sex, beating them, and murdering them.

While there are exceptions (Sokoloff and Dupont 2005), very few scholars are examining the structural, root causes of battering, especially in relation to the lived experiences of African American men. This paper has asked several difficult questions one being: "why do African American men batter the women they claim to love?" Analyzing batterers' own explanations for their behavior, I have woven the analysis together looking at individual and structural explanations, recognizing that as long as batterers remain characterized as "bad" men, without recognizing the root causes of their behavior, no effective programs will ever be developed that can make a difference, and battering will remain far too common in African American Civil Society (West 2004).

With the need to examine root causes from a new and different angle, this paper has utilized the theoretical work of Merton to explore the ways in which IPV can be understood-from the perspective of the batterer-as a behavioral response to alienation or anomie. This interpretation of IPV moves us beyond that which feminist scholars have developed by focusing our attention on the experiences of individual men as they navigate the changing social world. Specifically, this paper

\footnotetext{
${ }^{12}$ While I am interested in these very same issues among gay and lesbian African Americans, I do not address them here. See, especially Lemelle and Battle 2004. "Black masculinity matters in attitudes toward gay males." Journal of Homosexuality 47:39-51, Pattavina et al. 2007. "A comparison of the police response to heterosexual versus same-sex intimate partner violence." Violence Against Women 13:374394.
} 
considers the position of African American men who are marginalized. ${ }^{13}$ Certainly, as feminists note, they have access to the power imbued to them by patriarchy and their primary expression of this power is the violence they perpetrate against their female partners. But, this violence occurs inside a wider context in which the men I have studied, African American men in the middle and lower classes, are alienated from the very institutions that provide routes to successful breadwinning and thus the successful establishment of a masculine identity. These men experience discrimination in the labor market and for many, their incarceration experiences render them unable to find any gainful employment. Under this strain many African American engage in IPV as a way to reduce the strain and alienation they feel (Hooks 1990; Mullaney 2007; West 2004).

As noted, however, these feelings of relief are quickly replaced by the feelings of alienation they feel from their female partners as a result of the violence they perpetrated against them. In an attempt to reduce this strain, they cozy up to their intimate partners, woo them, in what is to the men, a sincere attempt to reestablish intimacy with the only person who supports them. This honeymoon phase typically provides relief for the batterer's feelings of alienation, but again, these feelings of alienation return when he finds himself back out in a social world that does not value or respect him. Thus the cycle of violence continues.

Analyzing IPV by understanding its roots in alienation helps to illuminate the chronic (rather than acute) patterns IPV takes. First, because generally men who are alienated from society do not find permanent relief in this condition of alienation; it is chronic and thus they are continually reacting to it, thus contributing to the chronic nature of IPV. Second, because the honeymoon phase does not develop empathy in the batterer, a condition that is necessary for him to change his behavior and return to the intimacy sought at the beginning of the relationship (Wesley and CraigHenderson 2006), his behavior increases rather than reduces alienation in his intimate relationship. Finally, interpreting IPV as experienced by the men who engage in it through the framework provided by Merton's concept of alienation allows us to see more clearly the role that alienation-from the social world, from one's partner-plays in the cycle of violence and underscores the reasons why IPV rarely occurs in isolation, as an acute condition, but generally becomes chronic.

Taking on this subject is important even though, as sociologist Wilson (1987) warned years ago, sensitive topics have always been politically debated and scholars have shunned their findings because of political agendas. ${ }^{14}$ This project is too important to shelve. The contribution this paper makes is to the small literature that addresses IPV from the perspective of the men who batter (Anderson and Umberson 2001). Adding to this literature my paper tells the story of African American men who are themselves perpetrators of IPV. In sum, we have to unlock the cycle of

\footnotetext{
${ }^{13}$ I note here that this does not mean that IPV is limited to marginalized men. The recent public display of male against female violence by Bishop Thomas W. Weeks III against his prominent wife Juanita Bynum is a case in point. Retrieved December 22, 2007. http://www.nytimes.com/2007/09/20/us/20preacher. html?pagewanted $=2 \&$ r $=1$.

${ }^{14}$ The contentious debates began after the 1965 issue of the "Black Family" report by Daniel Patrick Moynihan. Sociologist William J. Wilson summarizes the retreat by scholars from this area of research in his "Cycles of Deprivation and the Ghetto Underclass Debate" appearing as Chapter 1 in The Truly Disadvantaged (1987). 
violence from the perspective of the men who engage in it if we are ever to have any hope of reducing it and encouraging the healthy male-female relationships so vital and yet too rare in African American Civil Society. All of our attempts at preventing and interrupting IPV have focused on the "triggers." And, overall we have had very little success in reducing or preventing IPV. My analysis in this paper offers a unique approach. We desperately need programs and interventions that will prevent the "gun" from being loaded in the first place.

Acknowledgements Many friends and colleagues supported me through the research and writing of this paper. While I can not mention all of them, I do want to thank Associate Provost Mark Welker, Wake Forest University for the generous resources to travel and conduct the interviews. A special thanks goes to my colleague Professor Angela Hattery (Sociology; Wake Forest University) for her patience in answering my many questions about Intimate Partner Violence and her assistance in reading the many drafts of this paper.

\section{References}

Acker, J. (2006). Class questions, feminist answers. New York: Routledge.

Adams, D. (1988). Treatment models of men who batter: a profeminist analysis. In K. Y. a. M. Bograd (Ed.), Feminist Perspectives on Wife Abuse. Newbury Park, CA: Sage Publishers.

Allen, W., Teranishi, R., Dinwiddie, G., \& González, G. (2002). Kocking at freedom’s door: Race, equity and affirmative action in U.S. Higher Education. Journal of Public Health Policy, 23, 440-452.

Anderson, E. (2008). Against the wall: Poor, young, black, and male. Philadelphia, PA: University of Pennsylvania Press.

Anderson, K., \& Umberson, D. (2001). Gendering violence: masculinity and power in men's accounts of domestic violence. Gender and Society, 15, 358-380.

Bogat, A., Levendosky, A., \& Davidson, W. S. (2002). Understanding the intergenerational transmission of violence: From pregnancy through the first year of life. Washington, DC: US Department of Justice.

Browne, A. (1989). When battered women kill. New York: Free Press.

Brush, L. (2003). Gender and governance. Walnut Creek, CA: Alta Mira Press.

Brush, L. (2006). When abuse spills into work. In The Society for the Study of Social Problems. Montreal, Canada.

CDC. (2006). Understanding intimate partner violence fact sheet. Atlanta, Georgia: Centers for Disease Control and Prevention.

Cleaver, E. (1968). Soul on ice. New York: Dell Publishing Company.

CNN (2007). Student murdered, burned on patio grill. in CNN.

Collins, P. H. (2004). Black sexual politics: African Americans, gender, and the new racism. New York: Routledge.

Connell, R. W. (1995). Masculinities. Berkeley: University of California Press.

Connell, R. W. (1998). Masculinities and globalization. Men and Masculinities, 1, 3-23.

Connell, R., \& Messerschmdt, J. (2005). Hegemonic masculinity: Rethinking the concept. Gender and Society, 19, 829-859.

Dunlap, E., Golub, A., Johnson, B., \& Wesley, D. (2002). Intergenerational transmission of conduct norms for drugs, sexual exploitation and violence: A case study. British Journal of Criminology, 42, 1-20.

Durkheim, E., \& Simpson, G. (1979). Suicide: A study in sociology. New York: Free Press.

Eckholm, E. (2006). Plight deepens for black men, studies warn. In New York Times. New York.

Ehrensaft, M., \& Cohen, P. (2003). Intergenerational transmission of partner violence: A 20-year prospective study. Journal of Consulting and Clinical Psychology, 7, 741-753.

Epstein, C. (2007). Great divides: The cultural, cognitive, and social bases of the global subordination of women. American Sociological Review, 72, 1-22.

Franklin, C. (1984). The changing definition of masculinity. New York: Plenum.

Gates, H. L. (2004). Breaking the silence. In New York Times.

Glassner, B. (2000). The culture of fear: Why Americans are afraid of the wrong things. New York: Basic Books.

Gondolf, E. W. (2007). Culturally-focused batterer counseling for African-American men. Criminology \& Public Policy, 6, 341-366. 
Gondolf, E. (2008). Outcomes of case management for African-American men in batterer counseling. Journal of Family Violence, 23, 173-181.

Goodrum, S., Umberson, D. J., \& Anderson, K. L. (2001). The batterer's view of the self and others in. domestic violence. Sociological Inquiry, 71, 221-240.

Hamberger, K., Ambuel, B., \& Guse, C. (2007). Racial differences in battered women's experiences and preferences for treatment from physicians. Journal of Family Violence, 22, 259-265.

Hanson, R. K., Cadsky, O., Harris, A., \& Lalonde, C. (1997). Correlates of battering among 997 men: family history, adjustment, and attitudinal difference. Violence and Victims, 12, 191-208.

Hattery, A. J. (2008). Intimate partner violence. New York: Routledge.

Hattery, A. J., \& Smith, E. (2007). African American families. Thousand Oaks, California: Sage Publishers.

Hattery, A., \& Smith, E. (2008). Incarceration: A tool for racial segregation and labor exploitation. Race, Gender and Class forthcoming.

Hattery, A., Williams, M., \& Smith, E. (2005). The efficacy of the time out intervention program in Forsyth County. Winston-Salem, NC: Wake Forest University.

Hearn, J. (1998). The violences of men: How men talk about and how agencies respond to men's violence to women. Thousand Oaks, CA: Sage.

Heflin, C. M., \& Pattillo, M. (2006). Poverty in the family: Race, siblings, and socioeconomic heterogeneity. Social Science Research, 35, 804-822.

Hill, S. (2005). Black intimacies: A gender perspective on families and relationships. Lanham, MD: Altamira Press.

Hirschel, J. D., Hutchison, I. W., \& Dean, C. W. (1992). The failure of arrest to deter spouse abuse. Journal of Research in Crime and Delinquency, 29, 7-34.

Holtzworth-Munroe, A., \& Stuart, G. L. (1994). Typologies of male batterers: Three sub-types and the differences among them. Psychological Bulletin, 116, 476-497.

Hooks, B. (1990). When brothers are batterers-African Americans and domestic violence. Essence Magazine.

Hooks, B. (2004). We real cool:Black men and masculinity. New York: Routledge.

Howson, R. (2006). Challenging hegemonic masculinity. New York: Routledge.

Katz, J. (2006). The macho paradox: Why some men hurt women and how all men can help. Naperville, IL: Sourcebooks.

Kimmel, M. (1993). Clarence, William, Iron Mike, Magic - and US. Issues in Gender, Sex and Politics, $25,9-13$.

Kimmel, M. (2005a). The gender of desire: essays on male sexuality. Albany, New York: State University of New York Press.

Kimmel, M. (2005b). Manhood in America. New York: Oxford University Press.

Koss, M. P., Goodman, L. A., Browne, A., Fitzgerald, L. F., Keita, G. P., \& Russo, N. F. (1994). No safe haven: male violence against women at home, at work, and in the community. Washington, DC: American Psychological Association.

Lemelle Jr., A. J., \& Battle, J. (2004). Black masculinity matters in attitudes toward gay males. Journal of Homosexuality, 47, 39-51.

Lichtenstein, B. (2005). Domestic violence, sexual ownership, and HIV risk in women in the American deep south. Social Science and Medicine, 60, 701-714.

Marx, K., \& Engels, F. (1998). The German ideology. New York: Prometheus Books.

Mauer, M., \& Chesney-Lind, M. (2002). Invisible punishment: The collateral consequences of mass imprisonment. New York: The New Press.

McCall, N. (1994). Makes me wanna holla. New York: Random House.

Merton, R. K. (1968). Social theory and social structure. New York: The Free Press.

Merton, R. K. (1976). Sociological ambivalence and other essays. New York: Free Press.

Messner, M. (2007). Out of play: critical essays on gender and sport. Albany, New York: SUNY Press.

Mills, C. (1992). Ideology in Marx and Engels: Revisited and revised. The Philosophical Forum, 23, 301328.

Mincy, R. (2006). Black males left behind. Washington, DC: Urban Institute Press.

Mullaney, J. (2007). Telling it like a man: masculinities and battering men's accounts of their violence. Men and Masculinities, 10, 222-247.

Padavic, I., \& Reskin, B. (2002). Women and men at work. Thousand Oaks, CA: Pine Forge Press.

Pager, D. (2007). Marked: race, crime, and finding work in an era of mass incarceration. Chicago, IL: University of Chicago Press.

Parsons, T., \& Bales, R. (1955). Family, Socialization, and the interaction process. Glencoe, IL: Free Press. 
Pate, A. M., \& Hamilton, E. E. (1992). Formal and informal deterrents to domestic violence: The Dade county spouse assault experiment. American Sociological Review, 57, 691-697.

Pattavina, A., Hirschel, D., Buzawa, E., Faggiani, D., \& Bentley, H. (2007). A comparison of the police response to heterosexual versus same-sex intimate partner violence. Violence Against Women, 13, 374-394.

Patterson, O. (1999). Rituals of blood: Consequences of slavery in two American centuries. New York: Civitas.

Patterson, O. (2007). Jena, O. J. and the Jailing of Black America. In New York Times. New York.

Pettit, B., \& Western, B. (2004). Mass imprisonment and the life course: Race and class inequality in U.S. incarceration. American Sociological Review, 69, 151-169.

Potter, H. (2004). Intimate partner violence against African American women: The effects of social structure and black culture on patterns of abuse. PhD Thesis, Sociology, University of Colorado at Boulder, United States - Colorado.

Poussaint, A. (1972). Why blacks kill blacks. New York: Emerson Hall.

Rennison, C. (2003). Intimate partner violence, 1993-2001. Washington, DC: United States Department of Justice, Bureau of Justice Statistics.

Richards, L., \& Morse, J. (2007). Read me first for a user's guide to qualitative methods. Thousand Oaks, CA: Sage Publications.

Shelton, J., \& Wilson, G. (2006). Socioeconomic status and racial group interests among black Americans. Sociological Spectrum, 26, 183-204.

Sherman, L. W., Schmidt, J. D., Smith, D. A., \& Rogan, D. (1992). Crime, punishment, and stake in conformity: Legal and informal control of domestic violence. American Sociological Review, 57, 680691.

Smith, E. (2007). Race, sport and the american dream. Durham, North Carolina: Carolina Academic Press.

Smith, E., \& Hattery, A. (2007). If we build it they will come: The relationship between private prisons, incarceration rates, and prison industries in the US. Societies Without Borders, 2, 276-292.

Sokoloff, N. J., \& Dupont, I. (2005). Domestic violence at the intersections of race, class, and gender. Violence Against Women, 11, 38-64.

Straus, M., \& Gelles, R. (1995). Physical violence in American families. New Jersey: Transaction Publishers.

Therborn, G. (1980). The ideology of power and the power of ideology. London: Verso.

Tjaden, P., \& Thoennes, N. (2000). Full report of the prevalence, incidence, and consequences of violence against women: Findings from the national violence against women survey. Washington, DC: US Department of Justice.

Wacquant, L. (2001). Deadly symbiosis when ghetto and prison meet and mesh. Punishment and Society, 3, 95-133.

Walker, L. E. (1984). The battered woman syndrome. New York: Springer Pub. Co.

Wesley, L., \& Craig-Henderson, K. (2006). An exploratory study of the relationship between dispositional aggression and judgments about batterers among African American adults: Does more of the former influence the latter? Journal of Family Violence, 21, 487-495.

West, C. (2004). Black women and intimate partner violence. Journal of Interpersonal Violence, 19, $1487-1493$.

Western, B. (2006). Punishment and inequality in America. New York: Russell Sage Foundation.

Wilson, W. J. (1987). The truly disadvantaged: The inner city, the underclass, and public policy. Chicago, IL.: University of Chicago Press.

Wright, E. O. (1997). Class counts: comparative studies in class analysis. New York: Cambridge University Press. 